Original Research

\title{
Pengaturan Dinamis Tata Letak Denah Upacara Wisuda Universitas Surabaya
}

\author{
Felix Handani ${ }^{1 *}$, Jordan Valentino Lomanto ${ }^{1}$ \\ ${ }^{1}$ Fakultas Teknik, Universitas Surabaya, Raya Kalirungkut Surabaya-Indonesia 60293 \\ *corresponding author: felix.handani@staff.ubaya.ac.id
}

\begin{abstract}
Flexibility and Configurability software is important to accommodate a variety of managed data. In the graduation ceremony, the committee needs to arrange the graduation floor plan based on the provisions of each institution. The order of seating is adjusted based on the order of graduation of graduates with provisions agreed to each graduation period, such as the technical dimensions of the room and the order of priority of the predicate. During this time, the spreadsheet application used by the committee was inflexible. If the number of graduates increased or dimension of the blocks and floor plans is changed, the committee cannot flexibly change the plan. The factor of application flexibility and ease of configuration is needed. To support the flexibility of the configuration, the researcher observes the parameters of the sequence and floor plan, designs the database, displays the interface and adapts the activities carried out by humans into the system to automate the process of drawing a digital floor plan. The system requires graduate data, graduate predicate data, graduate faculty data, faculty sequence data, and floor plan data as preliminary data. The implementation of the stack can help the graduation of data storage implementation. With a flexible system, the committee's activities are reduced by $50 \%$ and the complexity of the committee's work is not influenced by the amount of graduate data. Adjustments to the layout of digital plans can be done at any time thereby increasing the flexibility of the committee in making decisions
\end{abstract}

Keywords: configurability, digital floor plan, graduation, stack

\begin{abstract}
Abstrak-Perangkat lunak yang dirancang dengan kemudahan konfigurasi dan fleksibilitas sangat diperlukan saat ini untuk mengakomodasi berbagai macam data yang dikelola. Dalam upacara wisuda, panitia perlu mengatur denah duduk wisudawan berdasarkan ketentuan institusi masing-masing. Urutan tempat duduk disesuaikan berdasarkan urutan pemanggilan wisudawan dengan ketentuan yang disepakati setiap periode wisuda, seperti teknis dimensi ruangan dan urutan prioritas predikatnya. Selama ini, aplikasi spreadsheet yang digunakan oleh panitia tidak fleksibel. Apabila jumlah wisudawan bertambah ataupun adanya pengubahan ukuran blok dan denah wisudawan, maka panitia tidak bisa secara fleksibel mengubah denah tersebut. Peran fleksibiltas aplikasi untuk menggambar denah secara digital dan kemudahan konfigurasi dibutuhkan. Untuk mendukung fleksibilitas dari konfigurasi tersebut, peneliti mengobservasi parameter penyusun urutan dan denah, merancang basis data, tampilan antar muka dan mengadaptasi aktivitas yang dilakukan oleh manusia ke dalam sistem untuk mengotomatisasi proses penggambaran denah digital. Sistem memerlukan data wisudawan, data predikat wisudawan, data fakultas wisudawan, data urutan fakultas dan data dimensi denah sebagai data awal. Penerapan struktur data stack membantu dalam mengimplementasi penyimpanan data wisudawan. Dengan sistem yang fleksibel, aktivitas panitia menjadi berkurang $50 \%$ dan kompleksitas pengerjaan panitia tidak dipengaruhi oleh jumlah data wisudawan. Penyesuaian susunan denah digital dapat dilakukan sewaktuwaktu sehingga meningkatkan fleksibilitas panitia dalam mengambil keputusan.
\end{abstract}

Kata kunci: denah digital, konfigurabilitas, stack, wisuda

\section{PENDAHULUAN}

Berbagai badan usaha pada era modern saat ini banyak menggunakan perangkat lunak sebagai alat bantu kerja. Perangkat lunak tersebut dikembangkan berdasarkan kebutuhan badan usaha sehingga dapat mengefisiensi dan mengefektifkan kerja dari para karyawan. Peran perangkat lunak juga penting dalam kecepatan dan ketepatan pengambilan keputusan sebuah perusahaan berdasarkan data yang terhimpun dari berbagai unit di dalamnya. Penggunaan perangkat lunak juga diterapkan untuk manajemen kegiatan pada upacara wisuda Universitas Surabaya.

Kegiatan wisuda Universitas Surabaya pada umumnya diselenggarakan pada bulan Maret dan September setiap tahun. Kegiatan wisuda diikuti oleh seluruh mahasiswa baik dari tingkat Diploma, Sarjana hingga Doktoral yang dapat mencapai ribuan wisudawan per event. Dalam pelaksanaanya, panitia perlu mempersiapkan berbagai hal salah satunya urutan pemanggilan wisudawan dan tata letak duduk wisudawan saat upacara berlangsung. Setiap periode wisuda, aturan terkait urutan pemanggilan wisudawan memiliki kebijakan yang beragam. Keberagaman tersebut terjadi faktor internal seperti kebijakan pimpinan, kebijakan 
panitia dan profil wisudawan yang mendaftar; dan faktor eksternal seperti tempat acara wisuda.

Penerapan perangkat lunak untuk pembentukan tata letak dan urutan denah selama ini sudah menggunakan aplikasi spreadsheet. Dengan mengurutkan kolom-kolom sesuai ketentuan sudah dilakukan dengan menggunakan fitur sort pada aplikasi per kolomnya, namun untuk memetakan dan mengelompokkan per fakultas dan predikat lulusan, panitia melakukan penyalinan dari lembar kerja satu ke lembar kerja lainnya. Penyalinan yang dilakukan oleh tiaptiap panitia memerlukan waktu yang cukup lama apabila data yang diproses dalam jumlah ratusan bahkan ribuan. Tantangan lain adalah kecepatan dalam memetakan urutan pemanggilan kepada denah tata duduk wisudawan berdasarkan dimensi tempat acara.

Dalam perangkat lunak modern, sistem perangkat lunak dikembangkan dengan mengedepankan kemudahan konfigurasi (Khouri \& Bellatreche, 2017). Kemudahan konfigurasi adalah sebuah parameter untuk mengukur kemampuan dari sebuah sistem dalam menjaga konsistensi hasil sesuai dengan parameter dan prosedur yang disepakati dengan berbagai bentuk data awal. Pengembangan sistem dengan kemudahan konfigurasi tinggi sudah dapat ditemui dari berbagai penelitian dan penerapan seperti pengembangan pada Enterprise Resource Planning (Kumar, \& Van Hillegersberg, 2000), penelitian terkait evolusi sistem pada Software Products Lines (Cirilo et al., 2013), dan pengembangan sistem Data Warehousing (Khouri \& Bellatreche, 2017). Untuk membentuk sistem yang konfigurabilitas tinggi, maka elemen dan data penyusun sistem harus dirancang sesuai dengan kebutuhan. Terlihat pada pengembangan sistem Data Warehousing, Khouri terlebih dahulu melakukan pengamatan dan penelitian bagaimana cara merancang basis data yang mendukung pada kasus Data Warehouse (Khouri \& Bellatreche, 2014).

Melihat permasalahan pengaturan tata letak wisudawan, penggunaan perangkat lunak dan sistem yang mudah dikonfigurasi dapat menjadi solusi. Untuk membentuk sistem yang mudah dikonfigurasi, peneliti ini menggunakan konsep stack untuk mendukung pengurutan berdasarkan parameter yang telah ditentukan sebelumnya. Stack (Cormen, Thomas H.; Leiserson, Charles E.; Rivest, Ronald L.; Stein, 2001) adalah konsep struktur data abstrak yang digunakan untuk menyimpan susunan berbagai macam data. Pola susunan dalam struktur data tersebut memberi makna urutan dari data yang tersimpan di dalamnya, di mana data yang memiliki dimasukkan terakhir akan dilayani terlebih dahulu. Di dalam stack terdapat dua operasi yang sesuai dengan kasus pengaturan tata letak yaitu operasi untuk memasukkan data pada kumpulan yang disebutu push, dan mengambil data yang disebut pop.

\section{METODE}

Metodologi penelitian dilakukan seperti pada Gambar 1. Peneliti melakukan observasi langsung dengan panitia pelaksana untuk mengetahui parameter dan proses pembuatan tata letak tempat duduk wisudawan. Peneliti melakukan pengamatan 2 sesi wisuda pada tahun 2018. Kemudian peneliti menuliskan poin-poin aktivitas yang dilakukan panitia pelaksana dalam membuat tata letak duduk wisudawan pada aplikasi spreadsheet.

Dari hasil temuan parameter tata letak, peneliti menyusun aktivitas baru yang dilakukan oleh panitia pelaksana. Peneliti menyusun rancangan basis data yang dipakai untuk menyimpan data konfigurasi dan menyimpan data wisudawan. Platform website digunakan untuk mempermudah akses dari berbagai perangkat. Peneliti mengimplementasi tampilan antar-muka untuk mengatur konfigurasi berdasarkan parameter-parameter yang ditemukan serta mengembangkan antar-muka untuk tata letak duduk wisudawan sesuai dengan platform dan bahasa pemrograman yang ditentukan. Penerapan stack diterapkan pada skrip tersebut untuk membantu mengelola data agar terstruktur. 


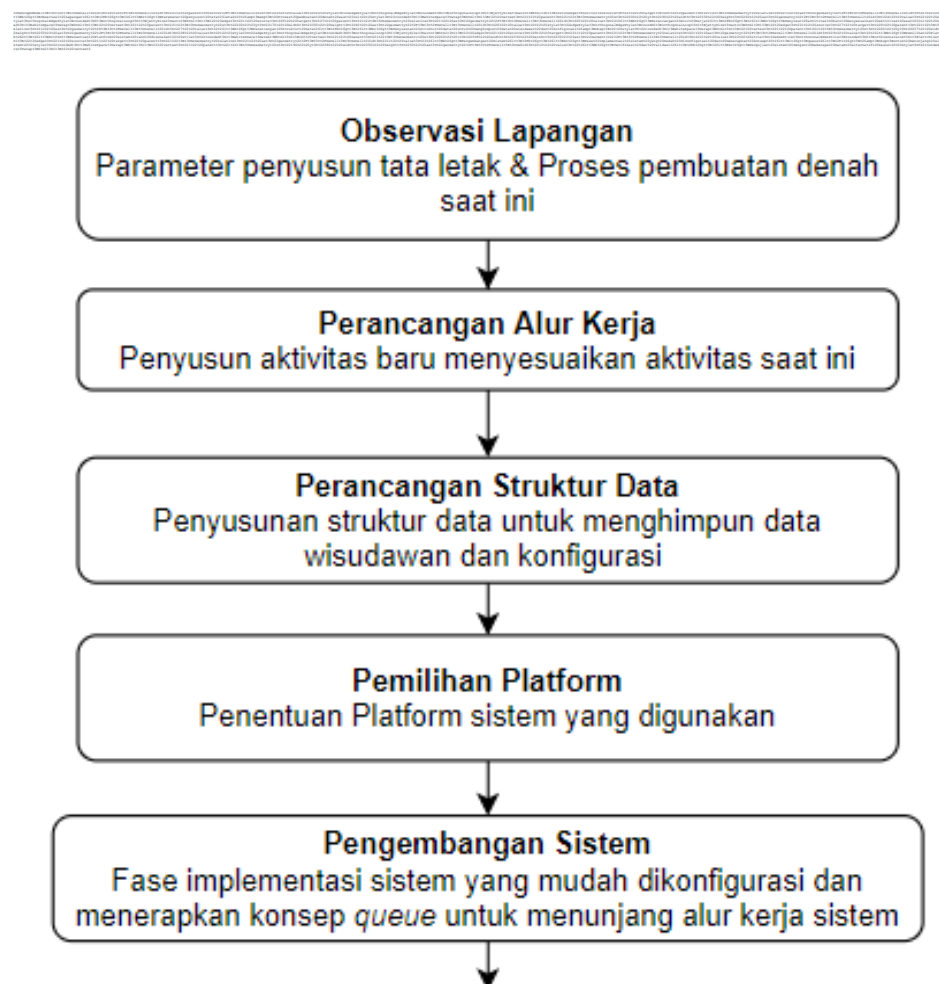

Gambar 1. Metodologi penelitian.

Peneliti membandingkan jumlah aktivitas yang dilakukan panitia dalam melakukan pembuatan denah sebelum dengan setelah menggunakan sistem. Peneliti kemudian mencari pengaruh nyata proses pembuatan tata letak denah wisudawan dari aspek kecepatan aktivitas dan fleksibilitas dari pembuatan denah terhadap pengubahan parameter.

HASIL

Bagian hasil menyampaikan temuan observasi awal beserta aktivitas awal yang dilakukan panitia pelaksana dengan menggunakan aplikasi spreadsheet. Kemudian dilanjutkan hasil rancangan basis data, proses yang dilakukan dan antar-muka pengguna dalam sistem berbasis website yang menunjang kebutuhan dari tata letak duduk wisudawan.

Berdasarkan observasi awal ditemukan lima parameter yang menjadi acuan dalam membuat urutan pemanggilan dan tata letak duduk wisudawan yaitu fakultas wisudawan, predikat kelulusan wisudawan, urutan nomor induk mahasiswa dan ukuran venue acara. Urutan Fakultas dalam beberapa tahun terakhir memiliki urutan yang sama yaitu berdasarkan urutan fakultas berdiri. Urutan predikat lulusan pada periode pertama diurutkan berdasarkan Summa-Cumlaude, Cumlaude dan tanpa predikat khusus. Namun pada periode kedua untuk mempermudah protokoler pemanggilan maka urutan diubah menjadi Summa-Cumlaude, tanpa predikat khusus dan Cumlaude. Nomor induk mahasiswa diurutkan dari nomor kecil hingga nomor besar pada beberapa tahun terakhir. Ukuran dan tata letak denah kursi wisuda memiliki pola yang sama yaitu 2 blok kolom dan banyak blok baris yang mana satu blok memiliki ukuran 17 memanjang horizontal dan 5 melebar vertikal. 


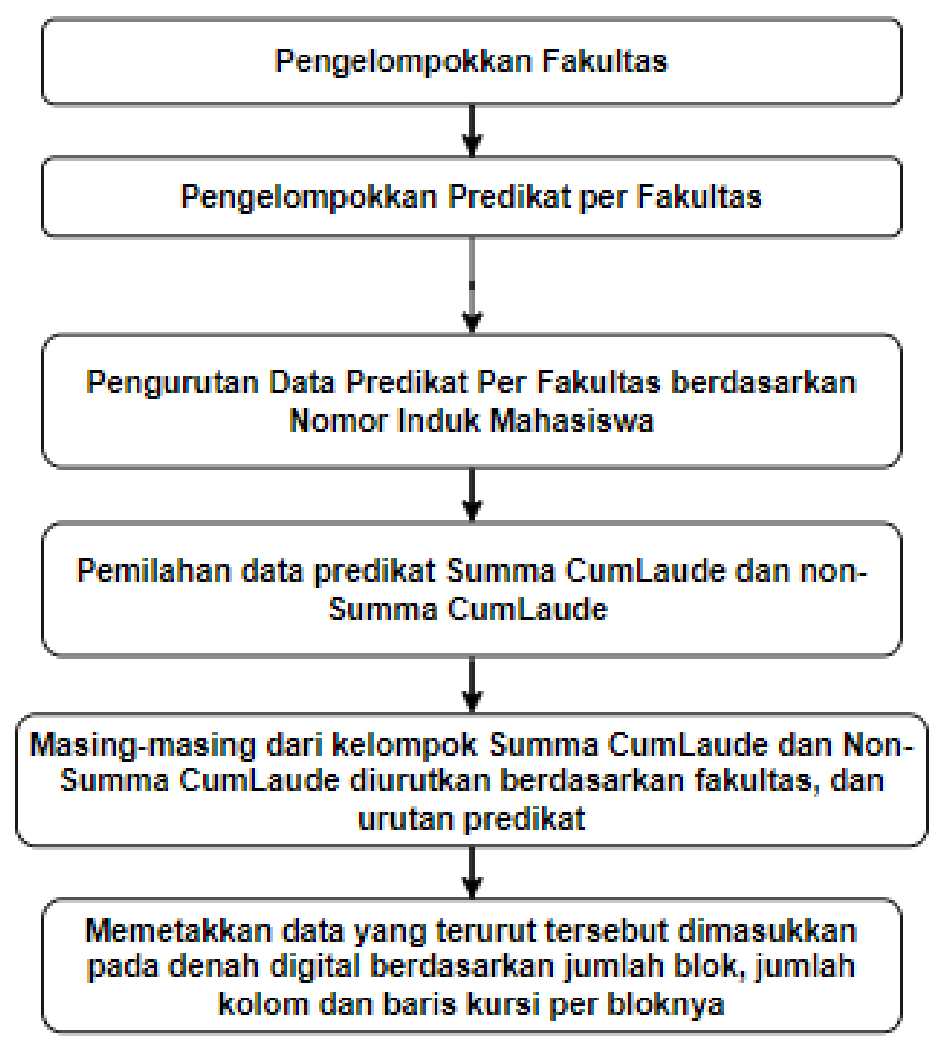

Gambar 2. Langkah kerja dan aktivitas pembuatan denah dengan spreadsheet.

Aktivitas yang dilakukan oleh panitia pelaksana pada aplikasi spreadsheet dimulai dengan mengambil data wisudawan dari aplikasi terintegrasi pada institusi. Data wisudawan kemudian dikelompokkan berdasarkan fakultas masing-masing dalam sheet tersendiri. Pada sheet tersebut, data wisudawan dikelompokkan berdasarkan predikat menjadi 3 kelompok yaitu Summa-Cumlaude, Cumlaude dan tanpa predikat. Dari kelompok kecil predikat tersebut, wisudawan diurutkan berdasarkan nomor induk.

Dalam pengaturan tata letak, beberapa baris paling depan pada tata letak diisi oleh wisudawan berpredikat summa-cumlaude dan diikuti wisudawan lainnya. Untuk mempermudah pengelompokan, panitia pelaksana membentuk 2 sheet baru yaitu: Sheet SummaCumlaude (SSC) dan Sheet Wisudawan (SW). Kedua sheet memiliki pola pengurutan yang sama yaitu urutan berdasarkan prioritas fakultas, urutan berdasarkan prioritas predikat dan urutan berdasarkan nomor induk. Mula-mula panitia pelaksana mengambil semua data berpredikat summa cumlaude dan diletakkan pada SSC. Urutan pengambilan berdasarkan konfigurasi dari urutan fakultas. Untuk mengisi SW, maka panitia pelaksana awalnya perlu mengurutkan kelompok kecil pada masing-masing fakultas berdasarkan prioritas predikat yang disepakati. Setelah data terurut, maka panitia mengambil satu per satu kumpulan data wisudawan dimulai dari urutan fakultas. Transformasi data dari aktivitas di atas terangkum dalam Gambar 3. 


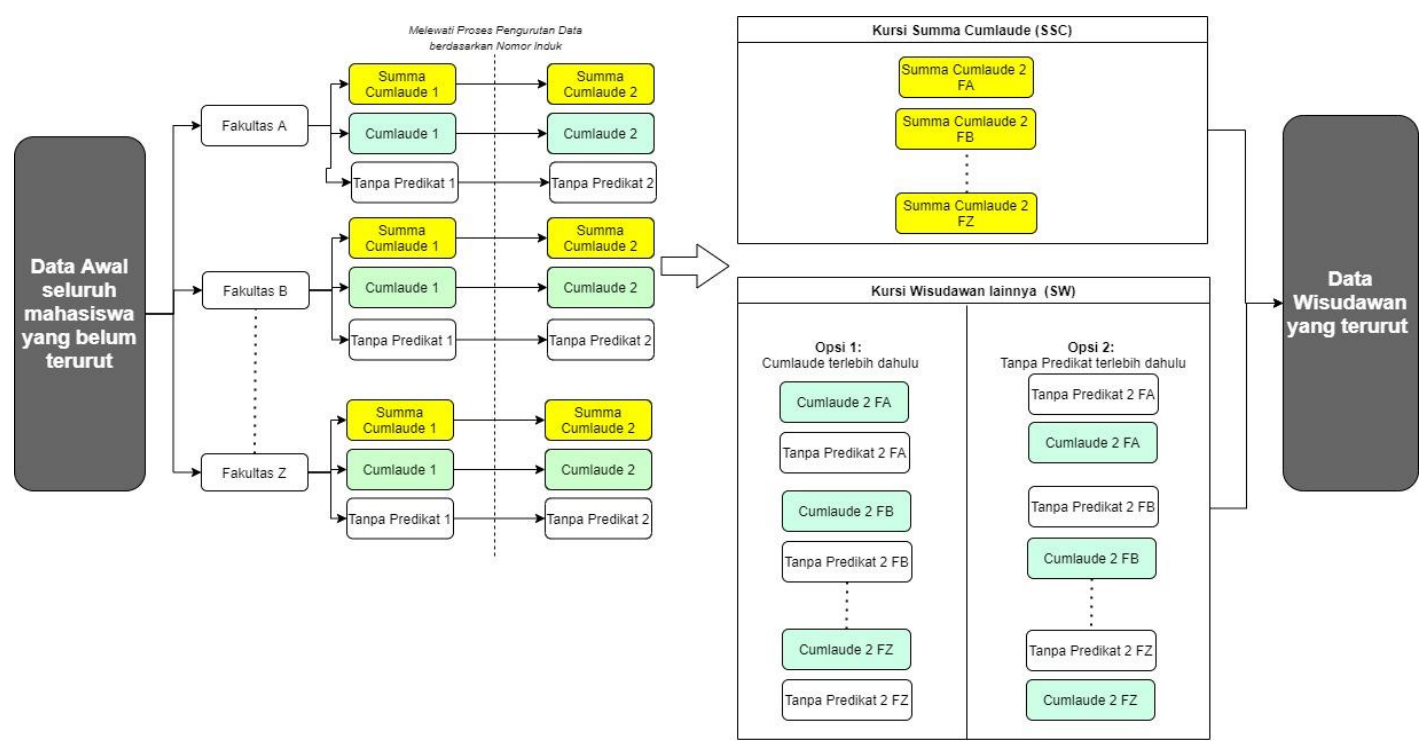

Gambar 3. Aktivitas perencanaan tata letak denah upacara wisuda.

Rancangan denah wisuda terbagi atas 2 bagian yaitu: blok kiri dan bagian kanan. Bila kelompok tatanan kursi Summa Cum Laude, urutan wisudawan Summa Cum Laude (SSC) dimulai dari kiri hingga blok kanan. Bila dalam satu baris awal tidak masih belum selesai menampung, maka perlu diatur 2 row pada kelompok kursi Summa Cum Laude. Kelompok kursi wisudawan lainnya (SW), urutan tempat duduk dimulai dari kiri depan lalu bergerka ke kanan hingga blok kiri habis sesuai dengan jumlah blok kursi paling belakang terisi. Kemudian masuk ke blok kanan pada kursi kiri depan hingga seluruh wisudawan terisi. Untuk menyimbangkan antara kursi blok kiri dan kanan, pada pengaturan ditambah parameter balancer dengan tujuan untuk menentukkan jumlah kursi yang harus ditambahkan pada sisi blok kiri paling belakang. Ilustrasi denah wisuda dapat dilihat pada Gambar 4.

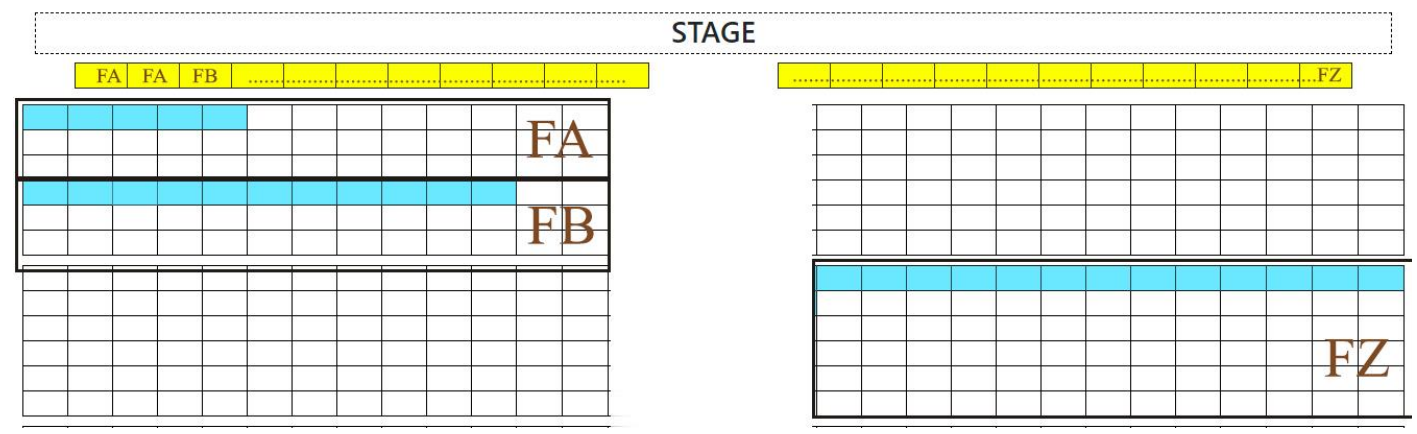

Gambar 4. Rancangan antara muka denah digital.

Basis Data dibuat dalam MySQL DBMS dengan memiliki dua tabel untuk menunjang sistem ini. Tabel tersebut adalah tabel Wisudawan, dan tabel Denah. Tabel Wisudawan menyimpan seluruh data wisudawan pada sebuah periode tertentu. Struktur data pada tabel Wisudawan terlihat pada Tabel 1 . Tabel Denah adalah tabel konfigurasi yang digunakan menyimpan seluruh parameter yang dibutuhkan dalam penyusunan denah digital. Struktur data pada tabel denah terlihat pada Tabel 2. 


\section{Tabel 1}

Struktur Data dari Tabel Mahasiswa

\begin{tabular}{|c|c|c|c|}
\hline No & Atribut & Tipe & Keterangan \\
\hline 1 & NRP & INT & Identifier unik dari data Mahasiswa \\
\hline 2 & Fakultas & VARCHAR & Kode Fakultas \\
\hline 3 & Nama & VARCHAR & Nama Wisudawan \\
\hline 4 & No Kursi & VARCHAR & Nomor Kursi Wisudawan \\
\hline 5 & Predikat & VARCHAR & $\begin{array}{l}\text { Mencatat Predikat Mahasiswa seperti 'Cum Laude', } \\
\text { 'Summa Cum Laude' }\end{array}$ \\
\hline
\end{tabular}

Tabel 2

Struktur Data dari Tabel Denah

\begin{tabular}{|c|c|c|c|}
\hline No & Atribut & Tipe & Keterangan \\
\hline 1 & ID & INT & Identifier unik dari setting Denah \\
\hline 2 & pr_row & INT & Jumlah baris untuk kursi Summa Cum Laude \\
\hline 3 & pr_column & INT & Jumlah kolom untuk kursi Summa Cum Laude \\
\hline \multirow[t]{2}{*}{4} & block & INT & Jumlah blok yang dibuat pada kursi non-Summa Cum \\
\hline & & & Laude \\
\hline 5 & row & INT & Jumlah baris pada blok kursi non-Summa Cum Laude \\
\hline 6 & balancer & INT & Jumlah kursi yang ditambahkan pada blok akhir \\
\hline \multirow[t]{3}{*}{7} & normal_setting & ENUM & Berisi urutan prioritas predikat. Data berisi: \\
\hline & & & a. 'cumlaude' $\rightarrow$ cumlaude dulu yang didahulukan \\
\hline & & & b. 'normal' $\rightarrow$ non-cumlaude dulu yang didahulukan \\
\hline
\end{tabular}

Alur aktivitas panitia pelaksana mengalami adaptasi karena beberapa proses telah diakomodasi oleh sistem. Panitia pelaksana cukup melakukan import data dengan csv dengan format basis data dari sistem ini. Kemudian panitia pelaksana melakukan penentuan jumlah blok, jumlah kolom dan baris dari setiap blok dan kursi Summa Cum Laude, melakukan penyesuaian terhadap berapa kursi yang ditambahkan dan menentukan pemanggilan untuk mendahulukan cumlaude ataupun non-cumlaude pada tampilan antar-muka sistem yang tertera pada Gambar 5. Proses transformasi data mulai dari pengelompokan fakultas, predikat hingga menggabungan data wisudawan yang terurut diakomodasi oleh proses sistem. Gambar aktivitas panitia pelaksana dengan menggunakan sistem terangkum pada Gambar 6 . 


\begin{tabular}{|c|c|c|c|c|c|c|c|c|c|}
\hline \multicolumn{2}{|c|}{$\nabla$ Bulk Actions - } & \multirow[b]{2}{*}{ 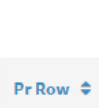 } & \multirow[b]{2}{*}{ PrColumn - } & \multirow[b]{2}{*}{ Block $=$} & \multirow[b]{2}{*}{ Row $=$} & T Sort \& Filter & Search & \multirow[t]{2}{*}{$a$} & \multirow{2}{*}{$\begin{array}{l}20 \vee \\
\text { Action }\end{array}$} \\
\hline & Periode Id $\triangleq$ & & & & & Column & Additional $*$ & & \\
\hline$\square$ & Maret 2020 & 1 & 15 & 5 & 6 & 15 & 0 & c & 10 \\
\hline$\square$ & September 2019 & 1 & 11 & 5 & 6 & 15 & 0 & c & 2 는 \\
\hline \multirow[t]{2}{*}{$\square$} & Maret 2019 & 2 & 11 & 5 & 5 & 15 & 8 & c & 10 \\
\hline & Periode Id & PrRow & Pr Column & Block & Row & Column & Additional & - & \\
\hline
\end{tabular}

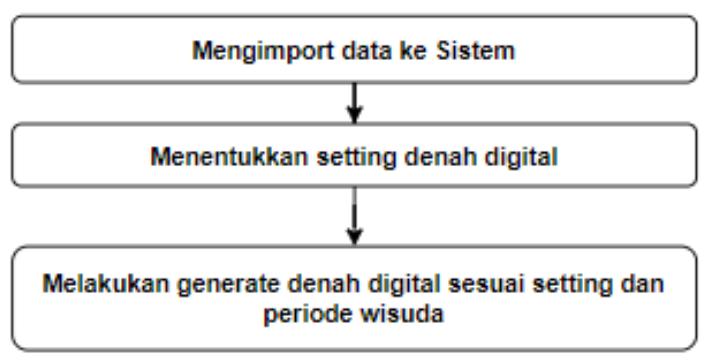

Gambar 6. Langkah kerja baru panitia pelaksana dalam membuat denah digital.

Aktivitas sistem dimulai dengan melihat konfigurasi denah yang telah dimasukkan sebelumnya. Kemudian sistem mengambil semua data wisudawan yang memiliki predikat 'Summa Cum Laude' pada periode yang aktif. Dari data-data wisudawan yang terhimpun, sistem memasukkan ke dalam array berbentuk struktur data stack yang menjadikan dasar dari urutan data yang akan digambar pada tampilan website. Proses penggambaran untuk predikat 'CumLaude' dan predikat lainnya sama dengan Summa Cum Laude. Pada akhirnya terdapat 2 buah variable bertipe stack yang siap disajikan untuk dirender dalam bentuk tampilan website. Untuk kode sumber implementasi terkait penerapan stack dapat melihat pada Gambar 8.

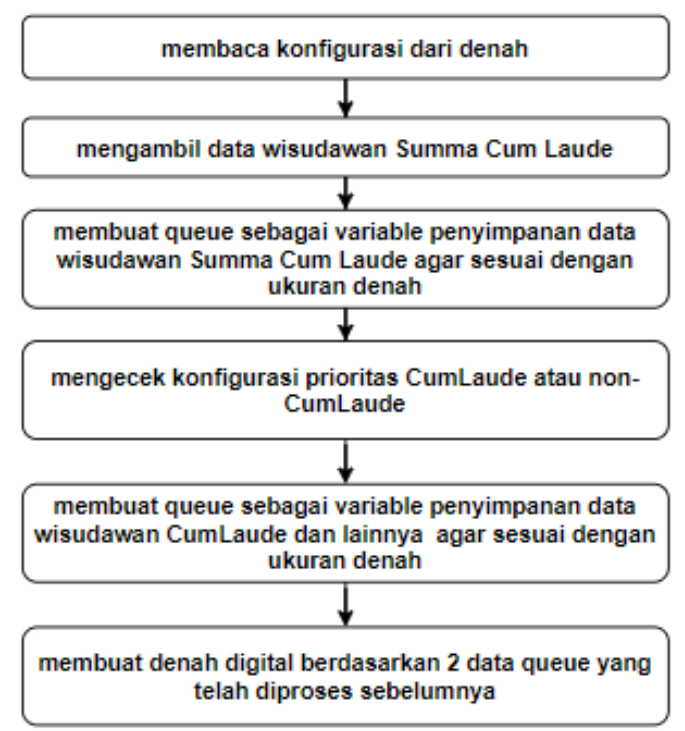

Gambar 7. Proses Sistem dalam membuat denah digital sesuai konfigurasi. 


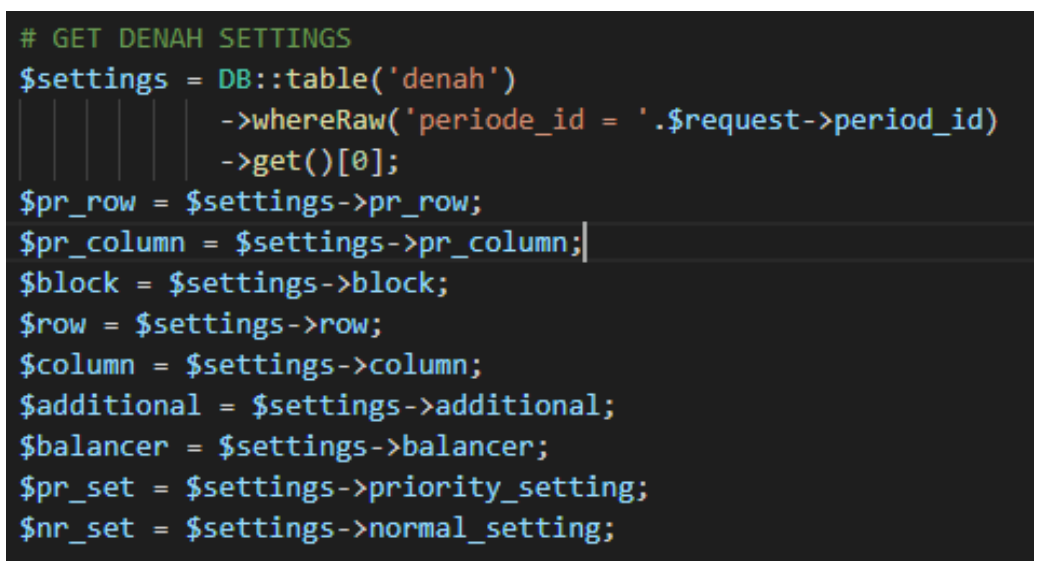

(a)

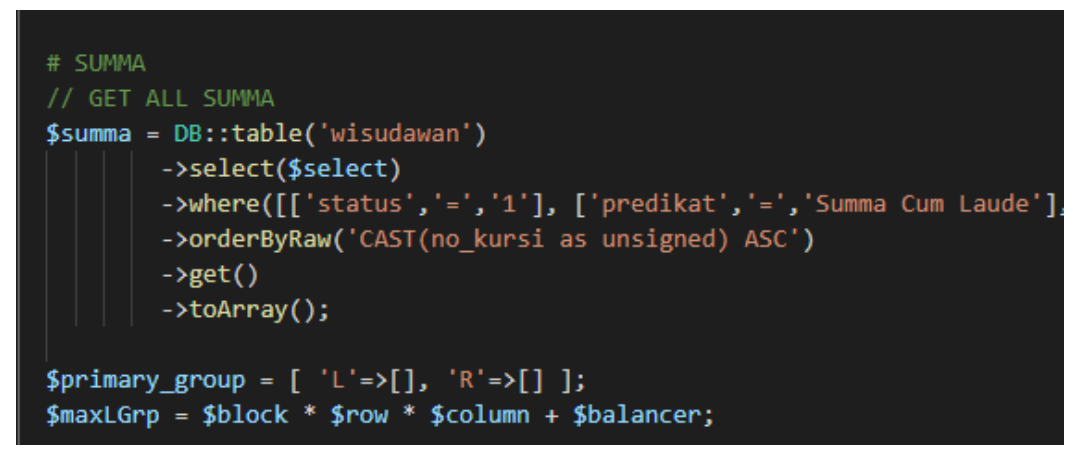

(b)

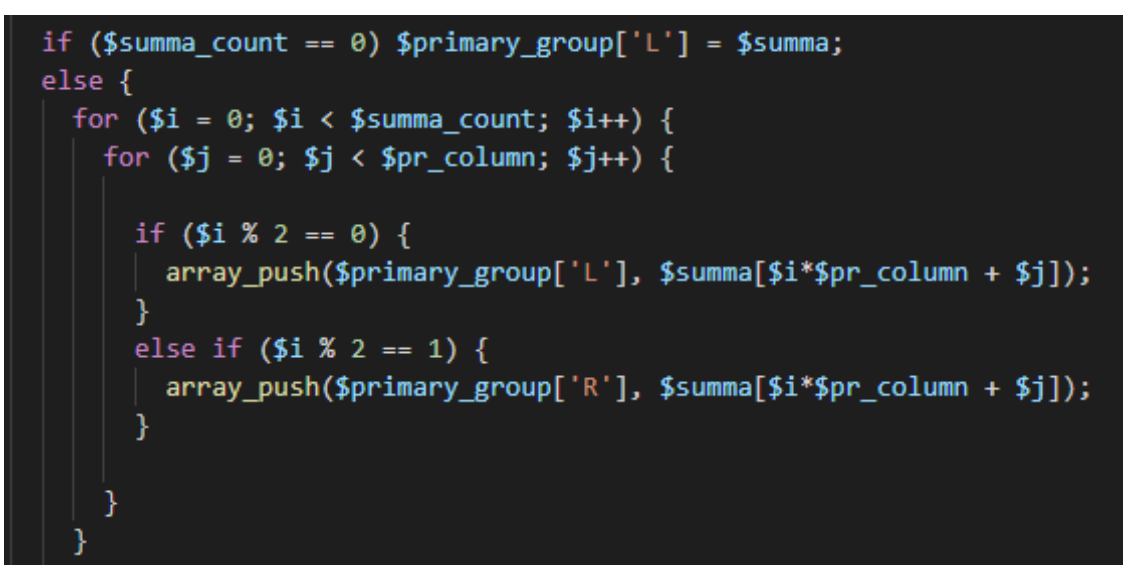

(c)

Gambar 8. (a) Listing Kode Sumber pengambilan Konfigurasi Denah; (b) Listing Kode Sumber pengambilan data wisudawan Summa Cum Laude; (c) Listing kode sumber penggunaan stack untuk menyimpan urutan data wisudawan.

Beberapa skenario ujicoba telah dilakukan untuk menguji kehandalan sistem dengan berbagai macam pola data yang ada. Skenario pertama dimulai dengan penetapan denah dengan 2 blok kolom dan 6 blok baris masing-masing blok memiliki $6 \times 17$ dengan data 1167 wisudawan. Konfigurasi diatur agar predikat non-Cumlaude terlebih dipanggil terlebih dahulu. Dari hasil deskripsi skenario pertama, maka dihasilkan sebuah ilustrasi pada Gambar 9 berikut ini. Terlihat data pada satu fakultas yang digambarkan pada warna tertentu, kode nomor yang tidak memiliki ' $C$ ' terletak lebih dahulu dibanding dengan kode nomor yang menggunakan ' $C$ '. Skenario kedua dimulai dengan 2 blok kolom dan 6 blok baris masing-masing blok memiliki 
6x17 dengan data 1183 wisudawan. Konfiguasi diurutkan untuk mendahului predikat cumlaude pada masing-masing fakultas. Dengan denah seperti ini didapatkan hasil pada Gambar 10. Terlihat data pada satu fakultas yang digambarkan pada merah dan putih untuk Fakultas Hukum dan Farmasi, maka ditemukan kode nomor yang memiliki ' $C$ ' terletak lebih dahulu dibanding dengan kode nomor yang tidak menggunakan ' $C$ '.

\begin{tabular}{|l|l|l|l|l|l|l|l|l|l|}
\hline 11915 & 6395 & 2435 & 12415 & 9395 & 10875 & 10855 & 10935 & 10965 \\
\hline
\end{tabular}

\begin{tabular}{|c|c|c|c|c|c|c|c|c|c|c|c|c|c|c|c|c|}
\hline 2 & 3 & 4 & 5 & 6 & 7 & 8 & 9 & 10 & 11 & 12 & 13 & 14 & 15 & 16 & 17 & 18 \\
\hline 19 & 20 & 21 & 22 & 23 & 24 & 25 & 26 & 27 & 28 & 29 & 30 & 31 & 32 & 33 & 34 & 35 \\
\hline 36 & 37 & 38 & 39 & 41 & 42 & 43 & 45 & 46 & 47 & 48 & 50 & 51 & 54 & 55 & 56 & 57 \\
\hline 58 & 59 & 60 & 62 & 63 & 64 & 65 & 66 & 67 & 68 & 69 & 71 & 72 & 73 & 74 & 76 & 77 \\
\hline 78 & 79 & 50 & 82 & 83 & 84 & 85 & 86 & 87 & 88 & 89 & 91 & 92 & 93 & 94 & 96 & 98 \\
\hline 99 & 100 & 101 & 103 & 104 & 105 & 106 & 107 & 108 & 109 & 110 & 112 & 113 & 115 & 116 & 117 & 119 \\
\hline 120 & 122 & 124 & 125 & 126 & 127 & 128 & 129 & 130 & 131 & 132 & 133 & 134 & 135 & 136 & 137 & 138 \\
\hline 141 & 142 & 143 & 144 & 145 & 146 & 147 & 148 & 149 & 150 & 151 & 152 & 153 & 154 & 155 & 157 & 158 \\
\hline 159 & 160 & 161 & 162 & 163 & 164 & 165 & 167 & 168 & 169 & 170 & 171 & 174 & 177 & 179 & 150 & 181 \\
\hline 182 & 183 & 184 & 185 & 186 & 188 & 189 & 190 & 191 & 192 & 193 & 194 & 195 & 196 & 197 & 198 & 199 \\
\hline 201 & 202 & 203 & 204 & 206 & 208 & 209 & 210 & 211 & 212 & 213 & 214 & 215 & 216 & 217 & 218 & 219 \\
\hline 220 & 222 & 224 & 225 & 226 & 227 & 228 & 229 & 230 & 231 & 232 & 233 & 234 & 235 & 236 & 237 & 1139 \\
\hline
\end{tabular}

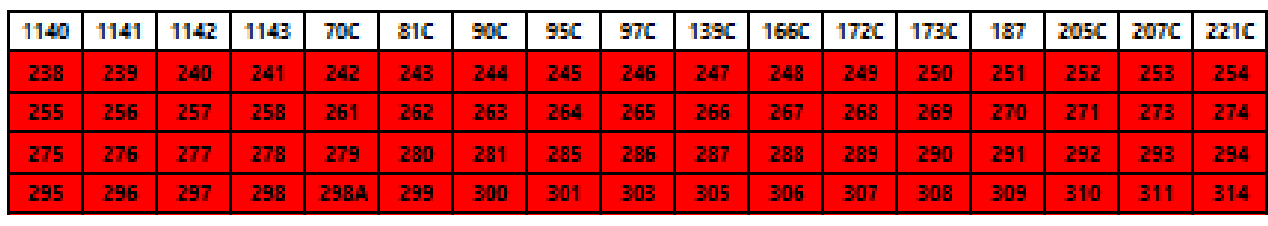

Gambar 9. Potongan hasil skenario pertama pada dua fakultas.

\section{BAHASAN}

Bila melihat jumlah aktivitas dalam melakukan pengurutan pemanggilan wisudawan, panitia pelaksana perlu melakukan 6 aktivitas apabila menggunakan spreadsheet. Kompleksitas proses setiap aktivitas dipengaruhi oleh jumlah peserta wisudawan yang mengikuti karena panitia pelaksana perlu mengurutan dan menyalin satu per satu dari sheet satu dan sheet lain. Dengan aktivitas penyalinan satu-persatu, semakin banyak data yang dikelola akan semakin tinggi risiko kesalahan pengelompokan dan sortir data. Berbeda dengan pengurutan pemanggilan wisudawan dengan menggunakan sistem, aktivitas panitia pelaksana dibantu oleh sistem sehingga panitia cukup melakukan 3 aktivitas. Aktivitas tersebut berfungsi sebagai pengaturan konfigurasi data awal dan denah yang akan digunakan. Aktivitas konfigurasi tidak berhubungan dengan jumlah data sehingga meminimalkan kesalahan.

Dalam membentuk denah digital dengan spreadsheet, panitia pelaksana juga perlu memindahkan data yang terurut baik dari kelompok Summa Cum Laude dan lainnya ke dalam template denah yang telah disepakati. Andaikata ada pengubahan ukuran blok dan ukuran panjang/lebar, maka panitia harus merekayasa ulang tatanan denah yang telah ada. Tentu aktivitas ini memakan waktu. Apabila menggunakan sistem, aktivitas panitia pelaksana lebih mudah karena panitia pelaksana cukup mengganti parameter denah yang akan digambar secara digital pada sistem. Program otomatis membuatkan bentuk gambar denah sesuai parameter yang ditentukan. 


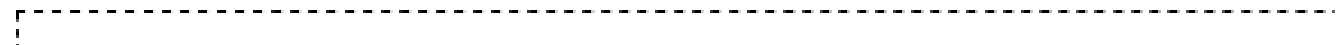

\begin{tabular}{|l|l|l|l|l|l|l|l|l|l|}
\hline 11915 & 6395 & 8435 & 12415 & 9395 & 10875 & 10885 & 10935 & 10965 \\
\hline
\end{tabular}

\begin{tabular}{|c|c|c|c|c|c|c|c|c|c|c|c|c|c|c|c|c|}
\hline $139 \mathrm{C}$ & $166 \mathrm{C}$ & $172 \mathrm{C}$ & $173 \mathrm{C}$ & 187 & $205 \mathrm{C}$ & $207 \mathrm{C}$ & $221 \mathrm{C}$ & $70 \mathrm{C}$ & $81 \mathrm{C}$ & $90 \mathrm{C}$ & $95 \mathrm{C}$ & $97 \mathrm{C}$ & 1 & 10 & 100 & 101 \\
\hline 103 & 104 & 105 & 106 & 107 & 108 & 109 & 11 & 110 & 112 & 113 & 115 & 116 & 117 & 119 & 12 & 120 \\
\hline 121 & 122 & 124 & 125 & 126 & 127 & 128 & 129 & 13 & 130 & 131 & 132 & 133 & 134 & 135 & 136 & 137 \\
\hline 138 & 14 & 140 & 141 & 142 & 143 & 144 & 145 & 146 & 147 & 148 & 149 & 15 & 150 & 151 & 152 & 153 \\
\hline 154 & 155 & 157 & 158 & 159 & 16 & 160 & 161 & 162 & 163 & 164 & 165 & 167 & 168 & 169 & 17 & 170 \\
\hline 171 & 174 & 177 & 179 & 18 & 190 & 181 & 182 & 183 & 184 & 185 & 186 & 188 & 189 & 19 & 190 & 191 \\
\hline 192 & 193 & 194 & 195 & 196 & 197 & 19 & 195 & 2 & 20 & 201 & 202 & 203 & 204 & 206 & 208 & 209 \\
\hline 21 & 210 & 211 & 212 & 213 & 214 & 215 & 216 & 217 & 218 & 219 & 22 & 220 & 222 & 224 & 225 & 226 \\
\hline 227 & 228 & 229 & 23 & 230 & 231 & 232 & 233 & 234 & 235 & 236 & 237 & 24 & 25 & 26 & 27 & 28 \\
\hline 29 & 3 & 30 & 31 & 32 & 33 & 34 & 35 & 36 & 37 & 38 & 39 & 4 & 41 & 42 & 43 & 44 \\
\hline 45 & 46 & 47 & 48 & 49 & 5 & 50 & 51 & 54 & 55 & 56 & 57 & 58 & 59 & 6 & 60 & 61 \\
\hline 62 & 63 & 64 & 65 & 66 & 67 & 68 & 69 & 7 & 71 & 72 & 73 & 74 & 75 & 76 & 77 & 78 \\
\hline 79 & 8 & 90 & 82 & 83 & 84 & 85 & 86 & 87 & 88 & 89 & 9 & 91 & 92 & 93 & 94 & 96 \\
\hline 98 & 99 & 1139 & 1140 & 1141 & 1142 & 1143 & $302 C$ & $304 \mathrm{C}$ & $312 \mathrm{C}$ & $313 \mathrm{C}$ & $318 \mathrm{C}$ & $321 \mathrm{C}$ & $322 \mathrm{C}$ & $339 \mathrm{C}$ & $344 \mathrm{C}$ & $352 \mathrm{C}$ \\
\hline $353 \mathrm{C}$ & $354 \mathrm{C}$ & $356 \mathrm{C}$ & $358 \mathrm{C}$ & $1148 \mathrm{C}$ & $1195 \mathrm{C}$ & 238 & 239 & 240 & 241 & 242 & 243 & 244 & 245 & 246 & 247 & 248 \\
\hline 249 & 250 & 251 & 252 & 253 & 254 & 255 & 256 & 257 & 258 & 261 & 262 & 263 & 264 & 265 & 266 & 267 \\
\hline 268 & 269 & 270 & 271 & 273 & 274 & 275 & 276 & 277 & 278 & 279 & 280 & 281 & 285 & 286 & 287 & 288 \\
\hline 289 & 290 & 291 & 292 & 293 & 294 & 295 & 296 & 297 & 298 & $298 \mathrm{~A}$ & 299 & 300 & 301 & 303 & 305 & 306 \\
\hline
\end{tabular}

Gambar 10. Potongan hasil skenario kedua pada dua fakultas.

Tabel 3

Tabel perbandingan aktivitas sebelum dan setelah menggunakan sistem

\begin{tabular}{|c|c|c|c|}
\hline No & Parameter Pembanding & Sebelum & Setelah \\
\hline 1 & $\begin{array}{l}\text { Jumlah Aktivitas yang } \\
\text { dilakukan manusia }\end{array}$ & 6 aktivitas & 3 aktivitas \\
\hline 2 & $\begin{array}{l}\text { Pengaruh jumlah data } \\
\text { terhadap kompleksitas } \\
\text { aktivitas }\end{array}$ & Berpengaruh & Tidak Berpengaruh \\
\hline 3 & Fleksibilitas pembuatan denah & Kurang Fleksibel & Fleksibel \\
\hline
\end{tabular}

\section{SIMPULAN}

Konsep perangkat lunak yang mudah dikonfigurasi (software configurable) membantu dalam mengefisiensi kerja dalam sebuah institusi. Terbukti pada sistem tata letak denah digital wisuda Universitas Surabaya mengefisiensi kerja panitia pelaksana hingga 50\% dari aktivitas sebelumnya. Penerapan struktur data stack dalam mengelola urutan wisudawan membantu peneliti dalam mengurutkan dan meletakkan data yang akan disajikan dalam bentuk denah. Panitia pelaksana tidak khawatir dengan jumlah kuantitas data wisudawan yang dikelola karena dengan penggunaan sistem ini, jumlah kuantitas wisudawan terhadap kompleksitas pekerjaan yang mereka lakukan tidak berpengaruh. Dalam memvisualisasi denah digital terhadap dimensi blok, kolom dan baris, sistem memungkinkan pengubahan visual sewaktuwaktu sesuai dengan konfigurasi yang telah disepakati bersama. 


\section{PUSTAKA ACUAN}

Cirilo, E, Kulesza, U, Garcia, A, Cowan, D, Alencar, P, \& Lucena, C 2013, 'Configurable software product lines - Supporting heterogeneous configuration knowledge', Lecture Notes in Computer Science (Including Subseries Lecture Notes in Artificial Intelligence and Lecture Notes in Bioinformatics), 7925 LNCS, 176-191. https://doi.org/10.1007/978-3-642-38977-1_12

Cormen, TH, Leiserson, CE, Rivest, RL, Stein, C 2001, 'Introduction to algorithms', Second Edition. In Introduction to Algorithms (2nd ed.).

Khouri, S \& Bellatreche, L 2014, 'Towards a configurable database design: A case of semantic data warehouses', Lecture Notes in Computer Science (Including Subseries Lecture Notes in Artificial Intelligence and Lecture Notes in Bioinformatics), 8841, 760-767. https://doi.org/10.1007/978-3-662-45563-0_47

Khouri, S, \& Bellatreche, L 2017, 'Design life-cycle-driven approach for data warehouse systems configurability', Journal on Data Semantics, Vol. 6, No. 2, pp. 83-111. https://doi.org/10.1007/s13740-017-0077-8

Kumar, K \& Van Hillegersberg, J, 2000, 'Erp Experiences and evolution', Communications of the ACM, Vol. 43, No. 4, p. 22. 